\title{
MODERN ANEURYSM SURGERY: A PRO-OPEN SURGERY VIEW
}

\author{
Dubovoy $A V^{1}$, Bervitskiy $A V^{2}$, Spallone $A^{3} \otimes$ \\ ${ }^{1}$ Federal Neurosurgical Center, Novosibirsk, Novosibirsk \\ 2 Yevdokimov Moscow State University of Medicine and Dentistry, Moscow \\ ${ }^{3} \mathrm{NCL}-$ Neuromed Institute of Neurological Sciences, Rome, Italy
}

\begin{abstract}
Modern management of intracranial aneurysms is matter of great debate between supporters of "traditional" microsurgical treatment and those of relatively new endovascular management. This paper briefly reports the experience of two experienced microvascular "traditional" neurosurgeons who shares the same management philosophy favouring open microsurgery in the modern era in which endovascular management is becoming fashionable. Difficult posterior circulation aneurysms are nowadays as a rule managed endovascularly, whilst anterior circulation aneurysms can be treated with both techniques, and MCA as well as distal ACA aneurysms are better treated microsurgically. Technical refinement and — hopefully- lower cost of endovascular devices will favour a trend of prevailing use of endovascular method in the future. However the need for wellprepared microvascular surgeon will always be there, and proper training of future generations of microvascular surgeons in a setting of decreasing number of patients and open surgical casuistics represents a big challenge for the neurosurgical community, to which an answer should be given.
\end{abstract}

Keywords: Intracranial aneurysms, microsurgery, cerebral revascularization, endovascular treatment, flow diverters, management guidelines, training

$\triangle$ Correspondence should be addressed: Aldo Spallone

Via Patrica 15, Rome, Italy, 00178; segreteria1@nclroma.it

Received: 28.06.2018 Accepted: 21.09.2018

DOI: $10.24075 / \mathrm{brsmu} .2018 .093$

\section{СОВРЕМЕННОЕ СОСТОЯНИЕ ХИРУРГИИ АНЕВРИЗМ: «ПРОМИКРОХИРУРГИЧЕСКИЙ ВЗГЛЯД}

\author{
А. В. Дубовой', А. В. Бервицкий ${ }^{1,2}$, А. Спаллоне ${ }^{3}$ \\ 1 Федеральный центр нейрохирургии, Новосибирск \\ ${ }^{2}$ Московский медико-стоматологический университет имени Е. И. Евдокимова, Москва \\ ${ }^{3} \mathrm{NCL}-$ Neuromed, Институт нейрологии, Рим, Италия
}

\begin{abstract}
Современные способы лечения пациентов с внутричерепными аневризмами являются предметом дискуссий между сторонниками традиционной микрохирургической техники и относительно нового эндоваскулярного лечения. В статье представлен опыт нейрохирургов - сторонников открытой микрохирургии. Сложные аневризмы задней циркуляции в настоящее время, как правило, оперируются эндоваскулярно, в то время как аневризмы переднего бассейна могут быть вылечены обоими методами, а для аневризм средней мозговой артерии и дистальных аневризм передней мозговой артерии лучше подходит микрохирургия. Техническое усовершенствование и, вероятно, снижение стоимости эндоваскулярных устройств будут способствовать тенденции к использованию эндоваскулярного метода. Однако потребность в хорошо подготовленных микрососудистых хирургах, на наш взгляд, останется, и надлежащая подготовка будущих поколений таких специалистов в условиях снижения числа пациентов и случаев открытых хирургических вмешательств представляет собой серьезную проблему для нейрохирургического сообщества, решение которой предстоит найти.
\end{abstract}

Ключевые слова: внутричерепные аневризмы, микрохирургия, реваскуляризация головного мозга, эндоваскулярное лечение

$\triangle$ Для корреспонденции: Альдо Спаллоне ул. Патрика, д. 15, г. Рим, Италия, 00178; segreteria1@nclroma.it

Статья получена: 28.06.2018 Статья принята к печати: 21.09.2018

DOI: 10.24075/vrgmu.2018.093

Optimal management of intracranial aneurysm is still matter of debate. The introduction in the clinical practice of endovascular techniques following the pioneer work of Serbinenko [1] and his group [2-5] has stimulated both researchers and industry to develop increasingly sophisticated technological items, coils [6] and more recently flow diverters [7-9] with the aim of excluding the aneurysm from the circulation and/or promoting its thrombosis while potentially reducing the stress to the patient and the invasiveness of the procedure.

However, debate is still going on and despite several large clinical trials no definitive conclusion has been reached [6, 1018]. As a matter of fact the experience of the treating surgeon, whether "classical" neurovascular surgeon or endovascular surgeon, seems to be the best discriminating factor for choosing the management strategy in each individual case nowadays.

Actually personal "traditional, hands-on" experience with difficult neurovascular surgery appears to be the prerequisite for competing with the "rising endovascular stars". This scenario may change in the future if the number of openly operated patients will decrease stepwise and consequently it would become difficult to give adequate training to future "open" neurovascular surgeons, and this will create a vicious circle following which open aneurysms surgery will progressively come to the end. 
However this would be not necessary so. The senior author (AS) has been fellow of Cooperative Study on aneurysm surgery in the 80's [19] and continued to believe that open surgery should keep a role in the management of aneurysm patients. He met recently an extremely interesting and highly qualified neurosurgical realty in Novosibirsk, Russia. In this setting he could verify and analyse the results of a management protocol which privileges open surgery for aneurysm patients, quite similar to the one used in Rome.

This paper reports the results of this management philosophy in a large series of aneurysms treated during a 3,5-year period.

\section{Results of the philosophy of treatment of a large series of aneurysms}

In 3,5-year time span starting in January 2014, 925 patients were managed by the authors. Due to the different referral characteristics, the overwhelming majority of the studied patients were treated in Novosibirsk. All surgeries were performed by either the first (AD) or the senior (AS) authors. Table 1 presents the main demographic data of patients.

The management protocol was quite similar in both Institutions and privileged open surgery. Ruptured aneurysms were operated on in the early stage whenever possible. Endovascular treatment, either by balloon or stent assisted coiling and, most recently, flow diverters was performed by experienced endovascular specialists who has been routinely involved in the management planning, on a-consultant ship base (in Rome) or as a staff member (in Novosibirsk).

Endovascular treatment was basically reserved to almost all posterior fossa aneurysms. As exception of this rule PICA aneurysms were operated microsurgically, although occasionally (6 cases) they were treated endovascularly. Anterior circulation aneurysms were as a rule treated with craniotomy unless the general clinical conditions of the patient contraindicated open surgery. Fusiform and giant aneurysms were subjected to wise case-by-case evaluation, and treated with flow diverters if trapping preceded by selective blood flow augmentation via a bypass, as well as direct clipping, were considered unfeasible. In particular giant cavernous ICA aneurysms were treated with carotid occlusion and ECIC bypass if there were signs of a intracavernous nerves compression (in order to avoid the risk of functional worsening due to aneurysm compaction and/or enlargement) and by flow diverters if they were asymptomatic, and CoA aneurysms were treated endovascularly only if close anatomical relationships with optic nerves were not the case. As far the bypasses, if the STA was of adequate size, a STAto-M3 bypass in the deep of the sylvian fissure was performed. Otherwise a high-flow bypass using a radial artery graft to either the MCA (28 cases) or the PCA (1 case) was performed. In four patients a A2 cross-link was performed, and in one patient a PICA-to-PICA anastomosis was confectioned. As a rule bypasses were performed prior to either main artery occlusion, aneurysm trapping or for blood augmentation in case of expected prolonged temporary clamping.

The use of flow diverters in the cases of difficult lesions of the basilar artery was indicated after a thoughtful discussion of all alternative management possibilities, due to the well-known risk of perforators compromise with using this technique in arteries which give off several, functionally very important, perforating branches. Figure 1 summarizes the management algorithm used in the present patient.

As a rule endovascular treatment was considered feasible only if the dome-to-neck ratio was less than $2: 1$. Otherwise, open treatment was considered mandatory. Obviously other hemodynamic and geometric factors were thoughtfully taken into consideration when deciding which type of management was the best for the patient.

\section{Patient characteristics and final outcome}

Among the patients there were 312 (33.7\%) men and $613(66.3 \%)$ women. Age ranged from 1 to 84 years and averaged 58 years. 286 patients (30.9\%) presented with SAH 64 of which (6.9\%) were operated in the acute stage. 184 patients (19.9\%) had multiple aneurysms, thus a total of 1162 aneurysms were operated. 119 (12.8\%) of them were large and giant. Aneurysms were localized on the internal carotid artery (ICA) in 480 cases (41.3\%), on the anterior cerebral-anterior communicating complex (ACA-AcoA) in 231 cases (19.8\%), on middle cerebral artery (MCA) in 290 cases $(24.9 \%)$, on the posterior cerebral artery (PCA) in 20 cases $(1.7 \%)$, on the basilar artery (BA) in 95 cases $(8.1 \%)$, on the superior cerebellar artery (SCA) in 23 cases $(2 \%)$, on the anterior inferior cerebellar artery (AICA) in 4 cases $(0.5 \%)$, and on the posterior inferior cerebellar artery (PICA) in 19 cases (1.7\%). 417 aneurysms (36\%) were operated by the endovascular method, $740(63.6 \%)$ microsurgically, $5(0.4 \%)$ had a combined therapy (endovascular occlusion + revascularization). Exclusion of the aneurysm in 99 (10.7\%) cases was supplemented by revascularization via 106 different anastomoses: in 15 cases intracranial micro anastomoses were performed, in 60 cases a STA-to-M3 by-passes, was confectioned, 2 patients had a bypass between maxillary artery and MCA with radial graft and 29 had a high-flow bypass using an interposed arterial segment

The results of surgery were evaluated 1 year after the operation. Among the 861 patients without SAH 842 (97.8\%) patients retained independent status, $17(2 \%)$ patients had severe disability, $2(0.2 \%)$ patient died. Out of the 64 patients operated in the acute period of $\mathrm{SAH}$, a good outcome was achieved in 51 (79.6\%) cases, 9 patients (14\%) were left disabled and 4 (6.4\%) patients died.

Main aneurysms characteristics, data of treatment modalities and results are summarized in Table 2.

\section{Disussion}

The debate between endovascular and open surgery as which would be the best method for treating intracranial aneurysms has characterized the last decade of neurovascular surgery. Refinement of technology together with increased experience [7-9] has shifted significantly the opinion of the general neurosurgical audience towards the idea that open aneurysms surgery would be close to its end. This brings two obvious consequences: increasing shortage of craniotomy-operated cases; consequent reduced capacity for adequately training the new generations in open neurovascular surgery. On the other hand careful evaluation of the results of endovascular surgery, even when using the most updated technology shows that this is not the panacea, and that other alternative methods

Table 1. Summarizes the main demographic data of the treated series

\begin{tabular}{|l|c|}
\hline Age (years) & $58.1(1-84$ years) \\
\hline Sex (male/female) & $312(33.7 \%) / 613(66.3 \%)$ \\
\hline History of SAH & $286(30.9 \%)$ \\
\hline No history of SAH & $640(69.1 \%)$ \\
\hline Acute SAH patients & $64(6.9 \%)$ \\
\hline
\end{tabular}

Note: SAH — subarachnoid hemorrhage. 
for treating aneurysms, in particular difficult aneurysms, are possibly still to be considered.

The main authors of this paper (AD and AS) met by chance and shared completely their personal opinion on this controversial issue. Both are aware that endovascular management can be in the future the management of choice for this pathology but this will require further technological advancement in the construction of the devices as well as, a very critical issue, significant lowering of the costs.

On the other hand in the nowadays scenario, open surgery still seems to play a significant, possibly a leading, role at least for treating anterior circulation aneurysms [20-23] and consequently adequate training of future generations, possibly uniformation of training criteria between different countries together with proper selection of the trainees who should be enough gifted and versed to difficult microsurgery, is an obligation for the present neurosurgical community.

It is out of the scope of the present paper to discuss in detail the specific aspects of the management protocol used in the present patients. Simply, we want to stress that it is based on the available clinical incidence and guidelines, whilst giving conceptual priority to microsurgery and all its available technical resources - including different methods of revascularization however utilising properly endovascular technique when considered more indicated on the basis of a thoughtful teambased discussion.

\section{Present results}

The present results were quite comparable to the largest series of intracranial aneurysm, reported in the recent literature, in which both methods, either microsurgical or endovascular approach, had been used, and match well with the results of a large series of intracranial aneurysm treated microsurgically, a significant number of which were also of large to giant size [24], reported less than a decade ago, in which surgical revascularization was considered a milestone in the management of technically demanding aneurysms. A main point is a sort of "cultural" integration between microsurgery experts and endovascular fellows which recognizes the proper, main role of direct surgery in the management of such a demanding lesions. In our environments there was an agreement on the fact that endovascular treatment was reserved to patients with unfavourable geometry, in which the placement of a by-pass could not guarantee from the later occurrence of ischemic complications should a major artery had to be closed for obliterating the aneurysm, and to technically formidable lesions of the posterior circulation.

One may argue that the particular type of referral of patients led to treating a relative minority of ruptured aneurysms, particularly in the acute stage. However, if this group of patients is analysed separately, the results are still very good. Again, we cannot under-consider the major role of properly used revascularisation techniques in the management of complex aneurysm, a fact already stressed by Cantore et al. [24] and reworked also very recently [25]. This in our view allowed us concretely to obtain good results in some very demanding cases. Again, the crucial importance of a proper hands-on training of microsurgical specialists cannot be overemphasized.

In a recently published critical review of modern aneurysms treatment, Rahal and Malek [26] suggested — wisely — that "a balance (should) be maintained between technical virtuosity and procedural safety of either (open or endovascular treatment modalities)". The problem remains has how to offer good quality training with enough large case material in order to prepare well a new generation of specialists if the significant stepwise decrease of patients managed with microsurgery observed in the last years will continue. The present experience suggests that well-prepared neurovascular surgeons can achieve good results, comparable to the published series of aneurysms patients, even if privileging open "traditional" neurovascular approach. In this respect an age-related limitation is maybe to be considered in order to keep the required technical standard for performing these demanding procedures.

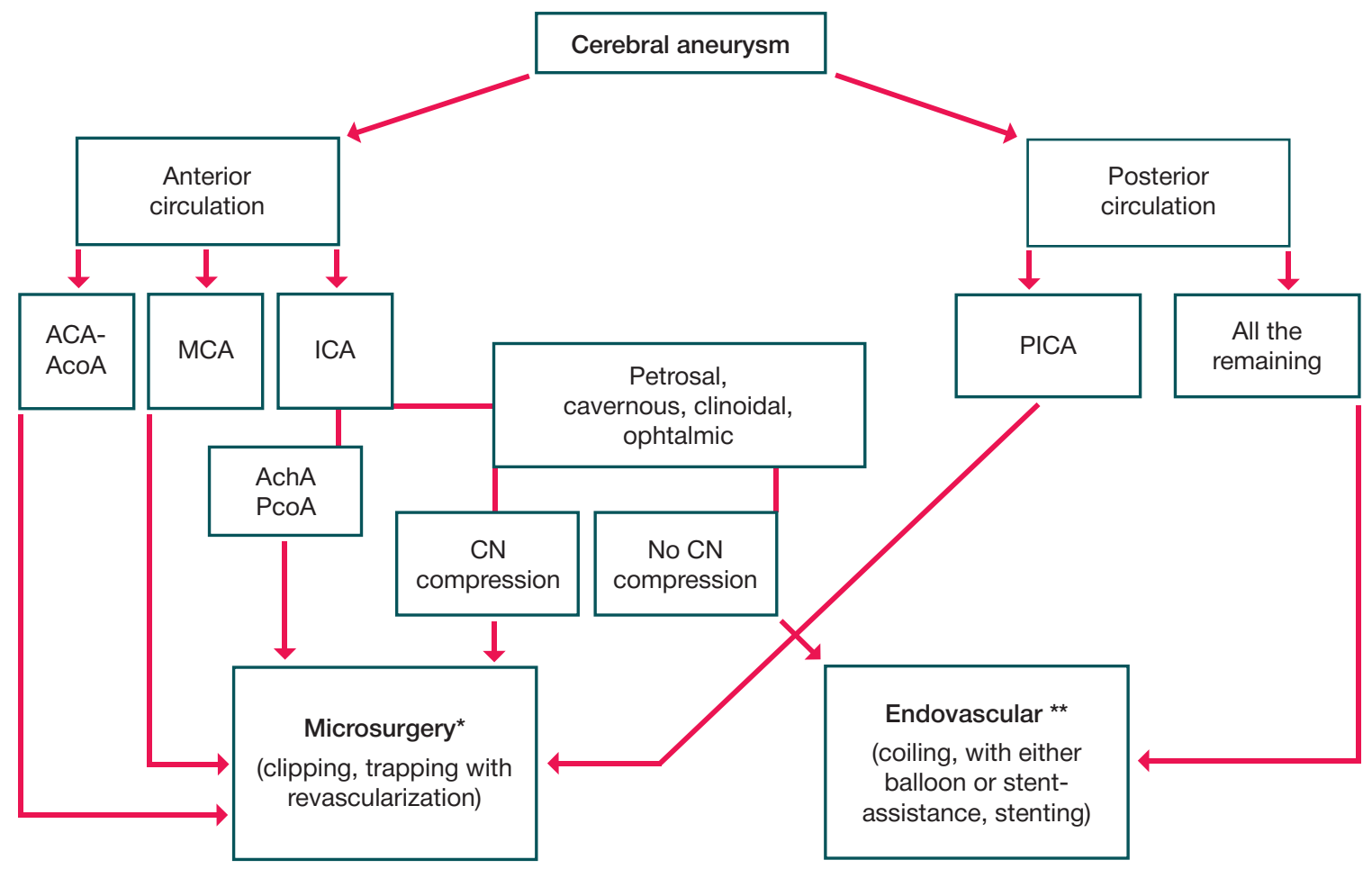

Fig. 1. Decision-making algorithm based on aneurysm location. * — except cases of general contraindications to open surgery, or patient individual choice; ** — except cases of allergic reactions for contrast 
Table 2. Aneurysms and treatment characteristics. Results

\begin{tabular}{|c|c|c|c|c|}
\hline Total number of aneurysms & \multicolumn{4}{|c|}{1162} \\
\hline Large and Giant & \multicolumn{4}{|c|}{$119(12.8 \%)$} \\
\hline Localization & Total & Endovascular & Microsurgery & Combined \\
\hline ICA & $480(41.3 \%)$ & 251 & 228 & 1 \\
\hline ACA-AcomA & $231(19.8 \%)$ & 16 & 215 & \\
\hline MCA & $290(24.9 \%)$ & 23 & 264 & 3 \\
\hline PCA & $20(1.7 \%)$ & 18 & 2 & \\
\hline $\mathrm{BA}$ & $95(8.1 \%)$ & 84 & 10 & 1 \\
\hline SCA & $23(2 \%)$ & 15 & 8 & \\
\hline AICA & $4(0.4 \%)$ & 4 & & \\
\hline PICA & $19(1.7 \%)$ & 6 & 13 & \\
\hline \multicolumn{5}{|l|}{ Revascularization } \\
\hline Intracranial & \multicolumn{4}{|c|}{15} \\
\hline STA-to-M3 & \multicolumn{4}{|c|}{60} \\
\hline Maxillary to MCA with graft & \multicolumn{4}{|c|}{2} \\
\hline High-flow bypass & \multicolumn{4}{|c|}{29} \\
\hline Results & Total & Unruptured $(n=861)$ & \multicolumn{2}{|c|}{ Acute SAH $(n=64)$} \\
\hline Independent & 893 & 842 & \multicolumn{2}{|c|}{51} \\
\hline Dependent & 26 & 17 & \multicolumn{2}{|c|}{9} \\
\hline Death & 6 & 2 & \multicolumn{2}{|c|}{4} \\
\hline
\end{tabular}

\section{Future guidelines}

Age-related changes affecting manual ability are physiological but also individual ones, so technical ability with demanding microsurgery can be maintained until different age in different individuals. The senior author (AS,) born 1952, decided himself to stop doing microsurgical by-passes a couple of years ago. Maybe a sort of "self-controlling tremor evaluation" using available sophisticated technology could be considered for objectively checking the technical capacity of each individual surgeon to perform safely delicate microvascular procedures, but this suggestion would not achieve easily wide acceptance. Also, as far as training in general, it should be noted that the first author achieved an objectively high degree of technical skill by long exercising with animal models and cadaver dissections even without making a specific clinical neurovascular fellowship in reputed institutions. In the selection of possible candidates for this difficult job, the individual characteristics (firm hand, calmness, strong emotional control — of fundamental importance in managing emergent situation during surgery) should be considered very carefully before let him/her spending long time in a difficult training program, and this concepts should have possibly serious consideration by the Committees in charge for establishing trainings guidelines. Also, the possibility to introduce a dual figure of both open and endovascular surgeon as the neurovascular expert in the future must also be considered, with its pros and contras. But again, sufficient case material of open neurovascular surgery would still be necessary, also because, apart from microvascular laboratory exercises with animal models, no other model possibly simulating the real clinical scenario of aneurysm surgery appears to be available nowadays.

\section{CONCLUSIONS}

In conclusion, open "traditional" neurovascular surgery, if performed with wise indications and management strategy by well-prepared neurovascular surgeons is still far from its end. The training of future generation is a challenge. Whether the future, in which significant technical improvement of endovascular devices is to be expected, will still give space to open neurovascular surgeons, or a dual figure of both open and endo-vascular expert will be the recommended solution, is likely to be matter of debate to be addressed to high- ranked training Committees. A strong recommendation to lower devices costs should come from the neurosurgical community.

\section{References}

1. Serbinenko FA. Balloon catheterization and occlusion of major cerebral vessels. J Neurosurg. 1974 Aug; 41 (2): 125-45.

2. Serbinenko FA. Balloon occlusion of saccular aneurysms of the cerebral arteries. [Article in Russian] Vopr Neirokhir. 1974 Jul-Aug; (4): 8-15.

3. Serbinenko FA. 7-year experience in endovascular surgery [Article in German]. Zentralbl Neurochir. 1977; 38 (2): 141-4.

4. Serbinenko FA. Six hundred endovascular neurosurgical procedures in vascular pathology. A ten-year experience. Acta Neurochir Suppl (Wien). 1979; 28 (1): 310-1.

5. Serbinenko FA, Filatov JM, Spallone A, Tchurilov MV, Lazarev VA.

Management of giant intracranial ICA aneurysms with combined extracranial-intracranial anastomosis and endovascular occlusion. J Neurosurg. 1990 Jul; 73 (1): 57-63.

6. Li H, Pan R, Wang H, Rong X, Yin Z, Milgrom DP et al. Clipping versus coiling for ruptured intracranial aneurysms: a systematic review and meta-analysis. Stroke. 2013 Jan; 44 (1): 29-37.

7. Kabbasch C, Mpotsaris A, Behme D, Dorn F, Stavrinou P, Liebig T. Pipeline Embolization Device for Treatment of Intracranial Aneurysms-The More, the Better? A Single-center Retrospective Observational Study. J Vasc Interv Neurol. 2016 Oct; 9 (2): 14-20.

8. Raymond J, Gentric JC, Darsaut TE, lancu D, Chagnon M, Weill A 
et al. Flow diversion in the treatment of aneurysms: a randomized care trial and registry. J Neurosurg. 2017 Sep; 127 (3): 454-62. DOI: 10.3171/2016.4.JNS152662. Epub 2016 Nov 4.

9. Brinjikji W, Lanzino G, Cloft HJ, Siddiqui AH, Kallmes DF. Risk Factors for Hemorrhagic Complications following Pipeline Embolization Device Treatment of Intracranial Aneurysms: Results from the International Retrospective Study of the Pipeline Embolization Device. AJNR Am J Neuroradiol. 2015 Dec; 36 (12): 2308-13.

10. Zhang $X$, Li L, Hong B, Xu Y1, Liu Y, Huang $Q$ et al. A Systematic Review and Meta-analysis on Economic Comparison between Endovascular Coiling versus Neurosurgical Clipping for Ruptured Intracranial Aneurysms. World Neurosurg. 2018 Feb 21; pii: S1878-8750(18)30349-8.

11. Alreshidi M, Cote DJ, Dasenbrock HH, Acosta M, Can A, Doucette J et al. Coiling Versus Microsurgical Clipping in the Treatment of Unruptured Middle Cerebral Artery Aneurysms: A Meta-Analysis. Neurosurgery. 2018 Feb 9. DOI: 10.1093/neuros/nyx623. [Epub ahead of print]

12. Fotakopoulos G, Tsianaka E, Fountas K, Makris D, Spyrou M, Hernesniemi J. Clipping Versus Coiling in Anterior Circulation Ruptured Intracranial Aneurysms: A Meta-Analysis. World Neurosurg. 2017 Aug; (104): 482-8

13. Xia ZW, Liu XM, Wang JY, Cao H, Chen FH, Huang J et al. Coiling Is Not Superior to Clipping in Patients with High-Grade Aneurysmal Subarachnoid Hemorrhage: Systematic Review and Meta-Analysis. World Neurosurg. 2017 Feb; (98): 411-20.

14. Ruan C, Long H, Sun H, He M, Yang K, Zhang H et al. Endovascular coiling vs. surgical clipping for unruptured intracranial aneurysm: A meta-analysis. Br J Neurosurg. 2015; 29 (4): 485-92.

15. Suzuki M, Yoneda $H$, Ishihara H, Shirao S, Nomura S, Koizumi H et al. Adverse events after unruptured cerebral aneurysm treatment: a single-center experience with clipping/coil embolization combined units. J Stroke Cerebrovasc Dis. 2015 Jan; 24 (1): 223-31.

16. Hwang US, Shin HS, Lee SH, Koh JS. Decompressive Surgery in Patients with Poor-grade Aneurysmal Subarachnoid
Hemorrhage: Clipping with Simultaneous Decompression Versus Coil Embolization Followed by Decompression. J Cerebrovasc Endovasc Neurosurg. 2014 Sep; 16 (3): 254-61.

17. Frontera JA, Moatti J, de los Reyes KM, McCullough S, Moyle H, Bederson JB et al. Safety and cost of stent-assisted coiling of unruptured intracranial aneurysms compared with coiling or clipping. J Neurointerv Surg. 2014 Jan; 6 (1): 65-71.

18. Brunken M, Kehler U, Fiehler J, Leppien A, Eckert B. Coiling vs. clipping: hospital stay and procedure time in intracranial aneurysm treatment. [Article in German] Rofo. 2009 Oct; 181 (10): 989-95.

19. Pasqualin A, Kassel NF, Torner JC, Benedetti A, Da Pian R, Guidetti B et al. Results of treatment (Article). Journal of Neurosurgical Sciences. 1988; 32 (1): 25-38.

20. McDougall CG, Spetzler RF, Zabramski JM, Partovi S, Hills NK, Nakaji $P$ et al. The Barrow Ruptured Aneurysm Trial. J Neurosurg. 2012 Jan; 116 (1): 135-44.

21. Spetzler RF1, McDougall CG, Albuquerque FC, Zabramski JM Hills NK, Partovi S et al. The Barrow Ruptured Aneurysm Trial: 3-year results. J Neurosurg. 2013 Jul; 119 (1): 146-57.

22. Spetzler RF, McDougall CG, Zabramski JM, Albuquerque FC, Hills NK et al. The Barrow Ruptured Aneurysm Trial: 6-year results. J Neurosurg. 2015 Sep; 123 (3): 609-17.

23. Spetzler RF, Zabramski JM, McDougall CG, Albuquerque FC, Hills NK, Wallace RC et al. Analysis of saccular aneurysms in the Barrow Ruptured Aneurysm Trial. J Neurosurg. 2018 Jan; 128 (1): 120-12.

24. Cantore G, Santoro A, Guidetti G, Delfinis CP, Colonnese C, Passacantilli E. Surgical treatment of giant intracranial aneurysms: current viewpoint. Neurosurgery. 2008 Oct; 63 (4) (Suppl 2): 279-90.

25. Tayebi Meybodi A, Huang W, Benet A, Kola O, Lawton MT. Bypass surgery for complex middle cerebral artery aneurysms: an algorithmic approach to revascularization. J Neurosurg. 2017 Sep; 127 (3): 463-79.

26. Rahal JP, Malek AM. Clip occlusion versus coil embolization for the treatment of cerebral aneurysms. J Neurosurg Sci. 2012 Sep; 56 (3): 175-90

\section{Литература}

1. Serbinenko FA. Balloon catheterization and occlusion of major cerebral vessels. J Neurosurg. 1974 Aug; 41 (2): 125-45.

2. Serbinenko FA. Balloon occlusion of saccular aneurysms of the cerebral arteries. [Article in Russian] Vopr Neirokhir. 1974 Jul-Aug; (4): 8-15.

3. Serbinenko FA. 7-year experience in endovascular surgery [Article in German]. Zentralbl Neurochir. 1977; 38 (2): 141-4.

4. Serbinenko FA. Six hundred endovascular neurosurgical procedures in vascular pathology. A ten-year experience. Acta Neurochir Suppl (Wien). 1979; 28 (1): 310-1.

5. Serbinenko FA, Filatov JM, Spallone A, Tchurilov MV, Lazarev VA. Management of giant intracranial ICA aneurysms with combined extracranial-intracranial anastomosis and endovascular occlusion. J Neurosurg. 1990 Jul; 73 (1): 57-63.

6. Li H, Pan R, Wang H, Rong X, Yin Z, Milgrom DP et al. Clipping versus coiling for ruptured intracranial aneurysms: a systematic review and meta-analysis. Stroke. 2013 Jan; 44 (1): 29-37.

7. Kabbasch C, Mpotsaris A, Behme D, Dorn F, Stavrinou P, Liebig T. Pipeline Embolization Device for Treatment of Intracranial Aneurysms-The More, the Better? A Single-center Retrospective Observational Study. J Vasc Interv Neurol. 2016 Oct; 9 (2): 14-20.

8. Raymond J, Gentric JC, Darsaut TE, lancu D, Chagnon M, Weill A et al. Flow diversion in the treatment of aneurysms: a randomized care trial and registry. J Neurosurg. 2017 Sep; 127 (3): 454-62. DOI: 10.3171/2016.4.JNS152662. Epub 2016 Nov 4.

9. Brinjikji W, Lanzino $G$, Cloft $H J$, Siddiqui $A H$, Kallmes DF. Risk Factors for Hemorrhagic Complications following Pipeline Embolization Device Treatment of Intracranial Aneurysms: Results from the International Retrospective Study of the Pipeline Embolization Device. AJNR Am J Neuroradiol. 2015 Dec; 36 (12): 2308-13.

10. Zhang X, Li L, Hong B, Xu Y1, Liu Y, Huang Q et al. A Systematic Review and Meta-analysis on Economic Comparison between Endovascular Coiling versus Neurosurgical Clipping for Ruptured Intracranial Aneurysms. World Neurosurg. 2018 Feb 21; pii: S1878-8750(18)30349-8.

11. Alreshidi M, Cote DJ, Dasenbrock HH, Acosta M, Can A, Doucette J et al. Coiling Versus Microsurgical Clipping in the Treatment of Unruptured Middle Cerebral Artery Aneurysms: A Meta-Analysis. Neurosurgery. 2018 Feb 9. DOI: 10.1093/neuros/nyx623. [Epub ahead of print]

12. Fotakopoulos G, Tsianaka E, Fountas K, Makris D, Spyrou M, Hernesniemi J. Clipping Versus Coiling in Anterior Circulation Ruptured Intracranial Aneurysms: A Meta-Analysis. World Neurosurg. 2017 Aug; (104): 482-8.

13. Xia ZW, Liu XM, Wang JY, Cao H, Chen FH, Huang $J$ et al. Coiling Is Not Superior to Clipping in Patients with High-Grade Aneurysmal Subarachnoid Hemorrhage: Systematic Review and Meta-Analysis. World Neurosurg. 2017 Feb; (98): 411-20.

14. Ruan $\mathrm{C}$, Long $\mathrm{H}$, Sun $\mathrm{H}, \mathrm{He} \mathrm{M}$, Yang $\mathrm{K}$, Zhang $\mathrm{H}$ et al. Endovascular coiling vs. surgical clipping for unruptured intracranial aneurysm: A meta-analysis. Br J Neurosurg. 2015; 29 (4): 485-92.

15. Suzuki M, Yoneda H, Ishihara H, Shirao S, Nomura S, Koizumi H et al. Adverse events after unruptured cerebral aneurysm treatment: a single-center experience with clipping/coil embolization combined units. J Stroke Cerebrovasc Dis. 2015 Jan; 24 (1): 223-31.

16. Hwang US, Shin HS, Lee SH, Koh JS. Decompressive Surgery in Patients with Poor-grade Aneurysmal Subarachnoid Hemorrhage: Clipping with Simultaneous Decompression Versus Coil Embolization Followed by Decompression. J Cerebrovasc Endovasc Neurosurg. 2014 Sep; 16 (3): 254-61. 
17. Frontera JA, Moatti J, de los Reyes KM, McCullough S, Moyle H, Bederson JB et al. Safety and cost of stent-assisted coiling of unruptured intracranial aneurysms compared with coiling or clipping. J Neurointerv Surg. 2014 Jan; 6 (1): 65-71.

18. Brunken M, Kehler U, Fiehler J, Leppien A, Eckert B. Coiling vs. clipping: hospital stay and procedure time in intracranial aneurysm treatment. [Article in German] Rofo. 2009 Oct; 181 (10): 989-95.

19. Pasqualin A, Kassel NF, Torner JC, Benedetti A, Da Pian R, Guidetti B et al. Results of treatment (Article). Journal of Neurosurgical Sciences. 1988; 32 (1): 25-38.

20. McDougall CG, Spetzler RF, Zabramski JM, Partovi S, Hills NK Nakaji $P$ et al. The Barrow Ruptured Aneurysm Trial. J Neurosurg. 2012 Jan; 116 (1): 135-44.

21. Spetzler RF1, McDougall CG, Albuquerque FC, Zabramski JM Hills NK, Partovi S et al. The Barrow Ruptured Aneurysm Trial: 3-year results J Neurosurg. 2013 Jul; 119 (1): 146-57.

22. Spetzler RF, McDougall CG, Zabramski JM, Albuquerque FC,
Hills NK et al. The Barrow Ruptured Aneurysm Trial: 6-year results. J Neurosurg. 2015 Sep; 123 (3): 609-17.

23. Spetzler RF, Zabramski JM, McDougall CG, Albuquerque FC, Hills NK, Wallace RC et al. Analysis of saccular aneurysms in the Barrow Ruptured Aneurysm Trial. J Neurosurg. 2018 Jan; 128 (1): 120-12.

24. Cantore G, Santoro A, Guidetti G, Delfinis CP, Colonnese C, Passacantilli E. Surgical treatment of giant intracranial aneurysms: current viewpoint. Neurosurgery. 2008 Oct; 63 (4) (Suppl 2): 279-90.

25. Tayebi Meybodi A, Huang W, Benet A, Kola O, Lawton MT. Bypass surgery for complex middle cerebral artery aneurysms: an algorithmic approach to revascularization. J Neurosurg. 2017 Sep; 127 (3): 463-79.

26. Rahal JP, Malek AM. Clip occlusion versus coil embolization for the treatment of cerebral aneurysms. J Neurosurg Sci. 2012 Sep; 56 (3): 175-90. 